\title{
LOCATION FACTORS OF FOREIGN AND DOMESTIC INVESTORS IN HOSPITALITY INDUSTRY IN POLAND
}

\author{
Daniel Puciato*, Agnieszka Gawlik**, Bolesław Goranczewski***
}

\begin{abstract}
Background. The choice of location of a hotel is one of the most important decisions taken at the pre-investment stage. Through the impact on the costs and revenues, it affects the hotel's profitability and other indicators of economic efficiency.

Research aims. The aim of the paper is an attempt to determine the most important location factors of foreign and domestic investors, to determine the motives of their choice.

Methodology. In this paper a deduction method diagnostic survey and statistical methods were used. The spatial scope of the survey comprised three provinces: Lower Silesia, Opole and Silesia, while the time covered the years 2000-2009.

Key findings. The analysis of results has shown that the most important factors for locations of hotels financed from national and foreign capital may differ. In the case of hotels with national origin of capital these factors include investment incentives planning and administrative investment incentives, intensification of competition, supply of tourist services in gastronomy, arts, and entertainment, as well as the availability of investment land. In contrast, in case of hotels with foreign and mixed capital the degree of the economy internationalisation and the urbanisation turned out to be statistically significant location factors.
\end{abstract}

Keywords: hotel, location, origin of capital, FDI (foreign direct investments), location factors, Poland

* The Wrocław School of Banking. E-mail: daniel.puciato@wsb.wroclaw.pl

** Opole University of Technology. E-mail: a.los@po.opole.pl

*** The Wrocław School of Banking. E-mail: boleslaw.goranczewski@wsb.wroclaw.pl 


\section{INTRODUCTION}

The management process is carried out by a continuous decision making at various levels of the organisational hierarchy and in different areas of management (Knapová, 2010; Roszkowska 2009). Although all decisions in enterprises are important, most attention is paid to the decisions of a strategic nature undertaken by top management. According to Romanowska (2008, p. 109), as they have particular importance because "the difficulty and risk of decision-making is growing with the increasing complexity of the problem and lengthening the time horizon of the decision." Incorrect decisions taken on top management levels can cause disastrous consequences for the manager, and above all for the organisation. One example of a strategic decision, burdened with high investment risk, is the choice of hotel location. Through the impact on the costs and revenues, it affects a hotel's profitability (Aissa \& Goaied, 2016) and other indicators of economic efficiency (Chung \& Kalnins, 2001; Sainaghi, 2011; Lado-Sestayo, Otero-González \& Vivel-Búa, 2014; Parte-Esteban \& Alberca-Oliver, 2015; Sohrabi et al., 2012; Lockyer, 2005; Łoś, 2012). The hotel's location is important for the costs of acquisition of land, construction of the hotel building and its operation (Silva, 2015). Location also affects the demand, seasonality of demand (Guizzardi \& Bernini, 2010), and the prices of hotel services (Abrate, Capriello \& Fraquelli, 2011), that affect the future financial income. The importance of the location selection process results from the fact that such a decision is long-term and it is associated with a high risk of changes in business conditions in a given location (Yang, Hao, \& Rob, 2014).

Despite the existence of the earlier papers on hotel location factors (e.g. Johnson \& Vanetti, 2005; Kundu \& Contractor, 1999; Zhang, Guillet \& Gao, 2012), there are few studies on the still less developed, but rapidly growing markets of Central and Eastern Europe. A good example is the Polish market, where two opposite tendencies can be observed. On the one hand, this market is still dominated by independent hotels, typically operating on the basis of domestic capital in the sector of small and medium-sized enterprises, which in 2015 represented approximately $63 \%$ of the Polish market (Rynek Hotelarski w Polsce Raport 2015). This is a feature that clearly distinguishes the Polish market from more developed markets, where the major role 
is played by multinational hotel corporations (Chen, 2010). On the other hand, like in other dynamically growing markets of Central and Eastern Europe, the expansion of foreign hotel corporations can be seen. Their relative share in the Polish market increased during the past few years from 15\% to 37\% (Rynek Hotelarski w Polsce Raport, 2015). There are both good and bad sides of this phenomenon.

The development of large modern hotels run by foreign operators is conducive to the modernisation of hospitality. Direct foreign investments (DFI) are considered to be an important factor in stimulating economic development in the hotel sector. The endogenous growth theory emphasises the role of human capital in particular, the positive effects of external effects of penetration and learning by doing (Rzepka, 2005, p. 52). In addition, FDI in the hotel industry have a positive impact on the level of services, the labour market and the innovative potential of hotel enterprises (Puciato, 2013, pp. 106-114; Starzyk, 1999, pp. 50-60). They are also associated, in addition to the influx of capital, with the transfer of technology, know-how, and solutions in the field of management and marketing (Gawlik \& Puciato, 2015). Nevertheless, all countries determined to host FDI in hospitality (including Poland) have to face a strong competition from other countries in Central and Eastern Europe that also wish to attract foreign investors. Consequently, a would-be host region endeavours to adjust factors underlying decisions on FDI and their location. At the same time progressively stronger involvement of foreign capital carries specific risks to the domestic enterprises (Przybylska, 1999). Some domestic hotels may not survive the new competitive environment, and could go bankrupt. In the face of a growing competition, these enterprises are faced with the need to search for strategic sources of competitive advantage. Their chance lies in the use of location benefits (Sala, 2006).

In previous papers, hotel location factors depending on the origin of financing capital, were not analysed. While, because of the power of capital, cost structure and the dominant strategy to maximise profit (cost or market orientation), the location factors for domestic investors may be different from those of concern to international hotel chains. In previous papers location factors of running a new hotel were rarely analysed. Usually, their authors focused only on already existing facilities. This seems important, both because of possible changes in the importance of particular location factors for investors as well as 
changes in their value. Reducing these specific research gaps, is one of the main tasks of this paper.

In the context of the presented introductory remarks, the main cognitive objective of this article is an attempt to identify the most important hotel location factors for domestic and foreign investors. The paper also has its practical purpose, which is to provide general recommendations on the proposed directions of activities of local and national authorities, aimed at improving the investment attractiveness of spatial units.

Due to the limited availability and high cost of collecting statistical data, the spatial extent of the research was limited to the area of south-western Poland, to provinces of Lower Silesia, Opole, and Silesia. These regions are the border regions (neighbouring Germany and/or the Czech Republic), and therefore they are characterised by a high degree of internationalisation and cross-border cooperation. At the same time they are diverse culture, socioeconomics, and natural heritage wise and they are characterised by different tourist attractiveness. Based on the study, "Investment Attractiveness of Regions" commissioned by the Polish Information and Foreign Investment Agency (Godlewska-Majkowska, 2013) it can be said that they are also characterised by diversified investment attractiveness in the area of hospitality. Top rated in this regard is Lower Silesia, due to a very well-developed infrastructure, a wealth of cultural, and natural values. An average grade is obtained by the Silesian region, which includes the country's largest conurbation with a potential development of business tourism. The Opole region gets the lowest category of the investment attractiveness in the area of hospitality in the group of the assessed provinces. The large regional diversity of this part of the country leads to the formulation of certain cautious assumptions concerning the entire Poland.

The time range of the research covered the years 2000-2009. The year 2000 was adopted as the beginning of the analysed period as this year can be acknowledged as the completion of the political transformation in Poland. The choice of 2009 as the end of the analysis stems from the fact that after 2009, there has been a soaring rate of growth in the Polish hotel market. This was primarily due to the occurrence of a "supply shock" resulting from Poland co-hosting the UEFA European Football Championships in 2012. The evaluation of conditions for hotel locations, for which the decision to start-up 
a facility was stimulated by this event, could, in the estimation of the authors, lead to the formulation of erroneous conclusions.

\section{LOCATION FACTORS FROM THE POINT OF VIEW OF THE ORIGIN OF CAPITAL}

Capital involvement in the country (region, town), is made by foreign and domestic investors on the basis of location preferences, imitation and/or previous experience. The next step is the specification of location factors affecting capital expenditures as well as future profitability of the business. An investor examines potential locations, based on the analysis of measures of location factors. Investors, after collecting the data and analysing them, rank possible locations and choose the best ones.

Location factors for all hotel enterprises can be divided into three main groups: the availability and cost of production factors, potential of the market, and stimulating instruments adopted by local authorities. In the first group of factors there are: investment costs (land availability and cost of the land) and operational costs (labour and transport costs). Investment costs should be carefully examined in the decision making process, especially since they shape such indicators as the return on equity and payback period. Labour costs constitute a very important location factor for all hotel enterprises (Ussi \& Wei, 2011; Gawlik \& Parvi, 2015; Grobelna, 2015). Labour costs depend on wage rates and labour productivity. Wage rates depend on demand and supply of labour, labour legislation and inconveniences in commuting to work or unions' strength. Labour productivity is, however, dependent on two groups of factors: attitudes towards work (staff turnover, absenteeism, reluctance to changes) and the degree of work organisation (technical infrastructure, innovation, strength and activity of trade unions). Labour costs and access to skilled personnel must be considered especially by hotels offering a wide range of services. These factors, according to theory of relative offsets of capital and labour costs, may be crucial in case of foreign investors. These are usually examined at the first stage of the decision-making process, to use comparative advantages (e.g. cheaper labour) of a less developed host country (Kojima, 1973). Transport costs can have a significant share in the operating cost structure, especially in the case of hotels, 
characterised by poor transport accessibility and the occurrence of non-availability of the workforce.

The importance of economic development the in process of searching for locations for new hotels, described in the literature (Adam \& Amuquandoh, 2013; Assaf, Josiassen \& Agbola, 2015; Baum \& Haveman, 1997; Chen, 2010; Demirbag, Tatoglu \& Glaister, 2007; Johnson \& Vanetti, 2005; Kundu \& Contractor, 1999; Luo \& Yang, 2012; Martorell, Mulet \& Otero, 2012; Puciato, 2012; Ramon Rodríguez, 2002; Shu \& Dai, 2002; Zhang, Guillet, \& Gao, 2012), results, among others, from the fact that the size and GDP growth strongly correlates with factors such as effective demand, price levels and price stability of production factors, access to modern transport infrastructure and information technology, quality of human capital and its costs. Investors for the reasons set out are usually interested in investing capital in countries (regions, municipalities) with a high level of economic development, or those that are characterised by high dynamics of this development. According to the research by Alegre and Cladera (2006), Assaf, Josiasseni and Agbola (2015), Brouthers, Brouthers and Werner (2000) as well as Johnson and Vanetti (2005) an important location factor is the stability level of the reception area, including political, economic, cultural, and legal stability. Low stability in each of these areas is associated with an increased risk of the investment, which causes that foreign investors do not invest in such places or choose the path of indirect investment (Kundu \& Contractor, 1999; Ramon Rodríguez, 2002).

The degree of internationalisation of the economy can also be an important condition of hotel location, especially for foreign investors (Assaf, Josiassen \& Agbola, 2015; Luo \& Yang, 2012; Kundu \& Contractor, 1999; Ramon Rodríguez, 2002; Martorell, Mulet \& Otero, 2012). The high degree of internationalisation means in fact generally low barriers to market entry (Martorell, Mulet \& Otero, 2012) and minor cultural differences between investors and the natives Barkema, Bell \& Pennings (1996), and Ramon Rodríguez (2002). The degree of cultural dissimilarities is manifested in psychological distance and language gap.

In the case of foreign investors, the urbanisation effect can be a particularly significant location factor (Yang, Wong \& Wang, 2012). It is associated with the presence in city centres of different business entities, large enterprises, special economic zones, science and technology parks 
that may determine a high demand for accommodation services. This effect also includes better access to suppliers and skilled employees. In addition, urbanisation means greater frequency and importance of organised sports, cultural and business events (Broadway, 1993; Zhang, Guillet \& Gao, 2012). Large mass events of an international character attract huge numbers of tourists. This involves in particular the development of such types of tourism as business, sport, or cultural tourism (Broadway, 1993; Hadzik \& Grabara, 2009; Szromek, Romaniuk \& Hadzik, 2016). Another important hotel location factor can be communication accessibility (Ferri, 2004; Yang et al., 2012). The best locations in this regard are city centres, city exit points, and areas around airports, train stations, and highways.

The volume of tourism demand is another important factor influencing the decision on the location of hotels in case of domestic and foreign investors (Kundu \& Contractor, 1999). The demand is shaped by the type and number of natural or anthropogenic tourist attractions (Ussi $\&$ Wei, 2011). Attractive natural and anthropogenic values, however, are often the main determinants of the size of leisure tourism demand. The importance of tourism values is particularly high in the case of holiday hotels, situated in places with a developed tourist function and hotel facilities located in cities abundant in interesting monuments and other human artefacts (Crecente et al., 2012; Hobson, 1994; Polyzos $\&$ Minetos, 2011; Sund, 2006). These factors can determine the size and the structure of demand for hotel services and, therefore, can be an important predictor of future profits.

It should be noted that the volume of the tourist supply can also influence location decisions concerning hotels with domestic and foreign capital (Puciato, Łoś \& Mrozowicz, 2013). This is mainly due to the fact that tourists, when choosing reception areas, are increasingly looking for products that could meet a variety of their needs. A large number of tourist enterprises may contribute to the growth of the tourist traffic in a specific location and attract foreign investors (Dziedzic, 1998).

Foreign and domestic investors are also taking into account the volume of supply in the hotel sector, e.g.: dominant segment of hotels, the spatial concentration of hotel operators, and the presence of cluster structures. On the one hand, a lot of competition in the segment of hotels of a similar standard could reduce the profitability of a future hotel, on the other hand it can bring the classic benefits 
of the agglomeration effect (Canina, Enz \& Harrison, 2005; Chung \& Kalnins, 2001; Egan, Chen \& Zhang, 2006; Yang \& Fik, 2011; Yang, Wong \& Wang, 2012; Zhang, Guillet \& Gao, 2012). According to a study by Chen and Dimou (2005), in case of financially strong foreign hotel chains with well-known brands, the second aspect is predominant. On the other hand, a large number of businesses operating on the local tourism market may negatively affect location decisions. An abundance of competitors can become a localisation barrier for domestic independent hotels.

The tourism policy conducted by the reception areas also may be an important location factor for both domestic and foreign investors. Assaf, Josiassen \& Agbola (2015), Buckley et al. (2007), Dębski \& Niemczak (2016), Martorell, Mulet \& Otero (2012), as well as Zhang, Guillet \& Gao (2012) indicate the importance of incentives aimed at attracting potential investors. These may be fiscal incentives (taxes and local fees - their rates and the possibility of postponing, remitting, abandoning or spreading out in instalments), planning and administrative (general strategies, strategies for tourism development, brand strategies, development plans, efficiency of administrative decisions, quality of real estate management, etc.), information (investment and economic advisory) and infrastructure (construction and modernisation of infrastructure).

The big differences between the domestic independent hotels and foreign hotels, cause that their location factors may differ. The same factors, therefore, have a different impact on investment decisions of domestic and foreign investors. In the case of foreign investors the presented factors are analysed at a local, regional, and national level. In the case of hotels with domestic capital these factors are analysed mainly from the local and regional perspective. The identified differences cause that studies of the location factors for new hotels, depending on the sources of capital, should be done in a separate way.

\section{MATERIALS AND METHODS}

The study was based on an examination procedure consisting of the following steps: (1) identification of the most important hotel location factors, (2) exploratory research of these factors and their final specification, and (3) empirical verification of location factors. 
During the first stage of the research, the literature content analysis method was used to analyse available references and on its basis factors determining location of chained-brand hotels were identified. This stage of research was based on the works of the following authors: Adam $\&$ Amuquandoh (2013), Chen \& Dimou (2005), Crecente et al. (2012), Egan, Chen \& Zhang (2006), Enz, Canina \& Liu (2008), Guizzardi \& Bernini (2010), Johnson \& Vanetti, (2005), Kundu \& Contractor (1999), Lado-Sestayo, Otero-González \& Vivel-Bua (2014), Martorell, Mulet \& Otero (2012), Parte-Esteban \& Alberca-Oliver (2015), Polyzos \& Minetos (2011), Puciato (2012), Puciato (2016), Puciato \& Dziedzic (2016), Ramon Rodriguez (2002), Shu Dai (2002), Yang \& Fik (2011), Yang, Wang \& Wong (2012), Zhang, Guillet \& Gao (2012).

Then the list of location factors based on the literature studies was tested in an explorative study. At this stage of the study, we used the diagnostic survey method - categorised depth interview. The research tool was a questionnaire, constructed by the authors, consisting of seven open questions regarding certain aspects of the hotel location and specifications of the respondents. The questions from the main part of the questionnaire included: course of the location selection process, possible consideration of other alternative locations for the hotel, location factors considered by investors in the decision-making process, sources and methods used in gathering information about the potential locations. In the specifications of the respondents there were questions pertaining to such features of the hotel, as legal form, ownership form, company size (number of employees and annual net turnover), standard, type, origin of capital, and the number of rooms and beds. The questionnaire was validated in pilot studies and all spotted errors and ambiguities were fixed. Surveys (interviews) with owners or managers of hotels were conducted in the first half of 2011. The sample selection was purposeful; 26 hotels were selected (13 financed from domestic and 13 from foreign capital), whose owners have expressed their willingness to participate in the survey. This represented about $32 \%$ of all hotels, launched in the provinces in 2000-2009.

In this phase of the research we analysed the survey results and made their comparison with the results of content analysis of literature. Consequently, by using inter alia: abstraction, reduction, or generalisation, we made a specification of the most important hotel location factors and their measures to make it possible to use the statistical analysis (Table 1). 


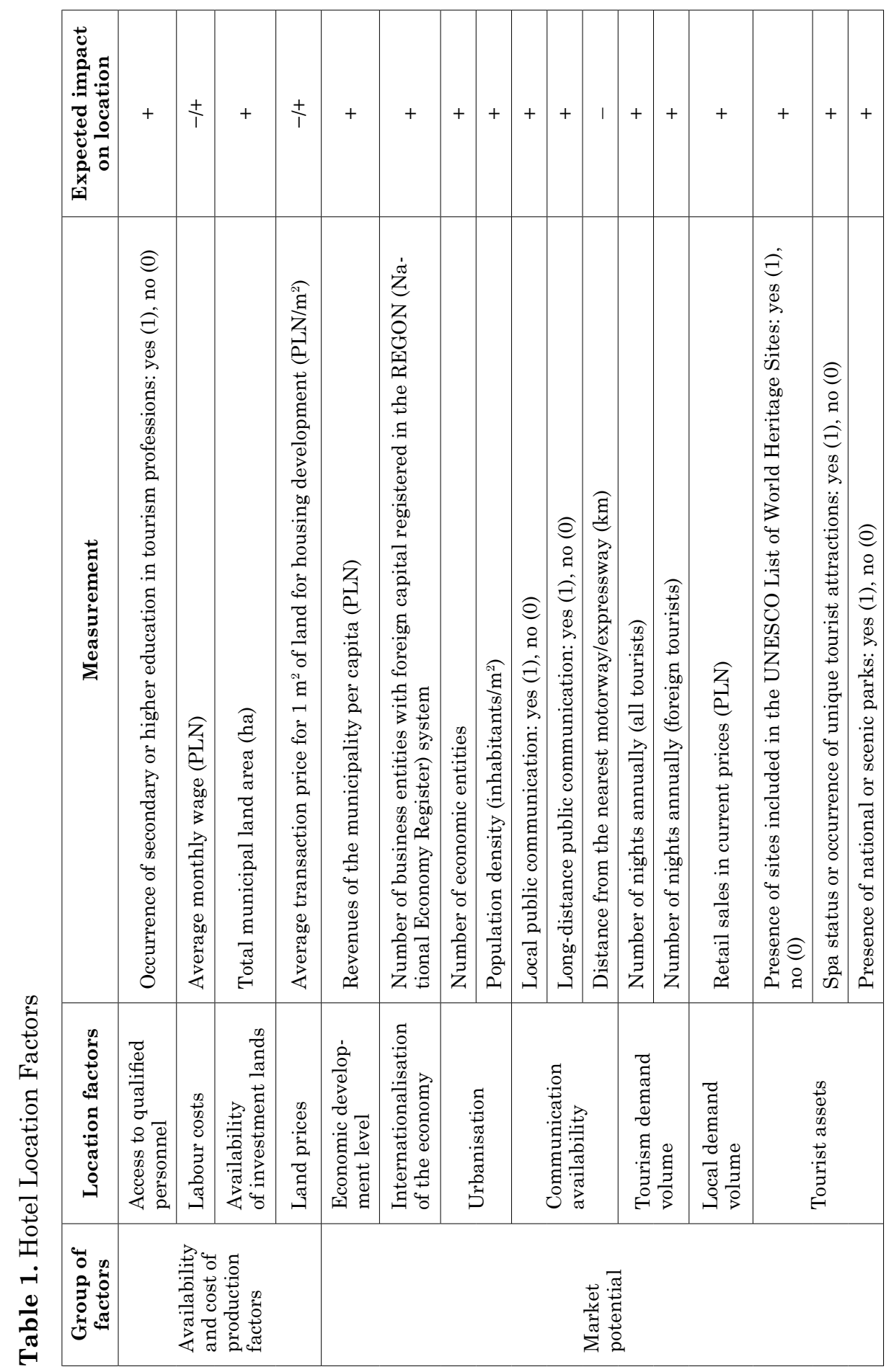




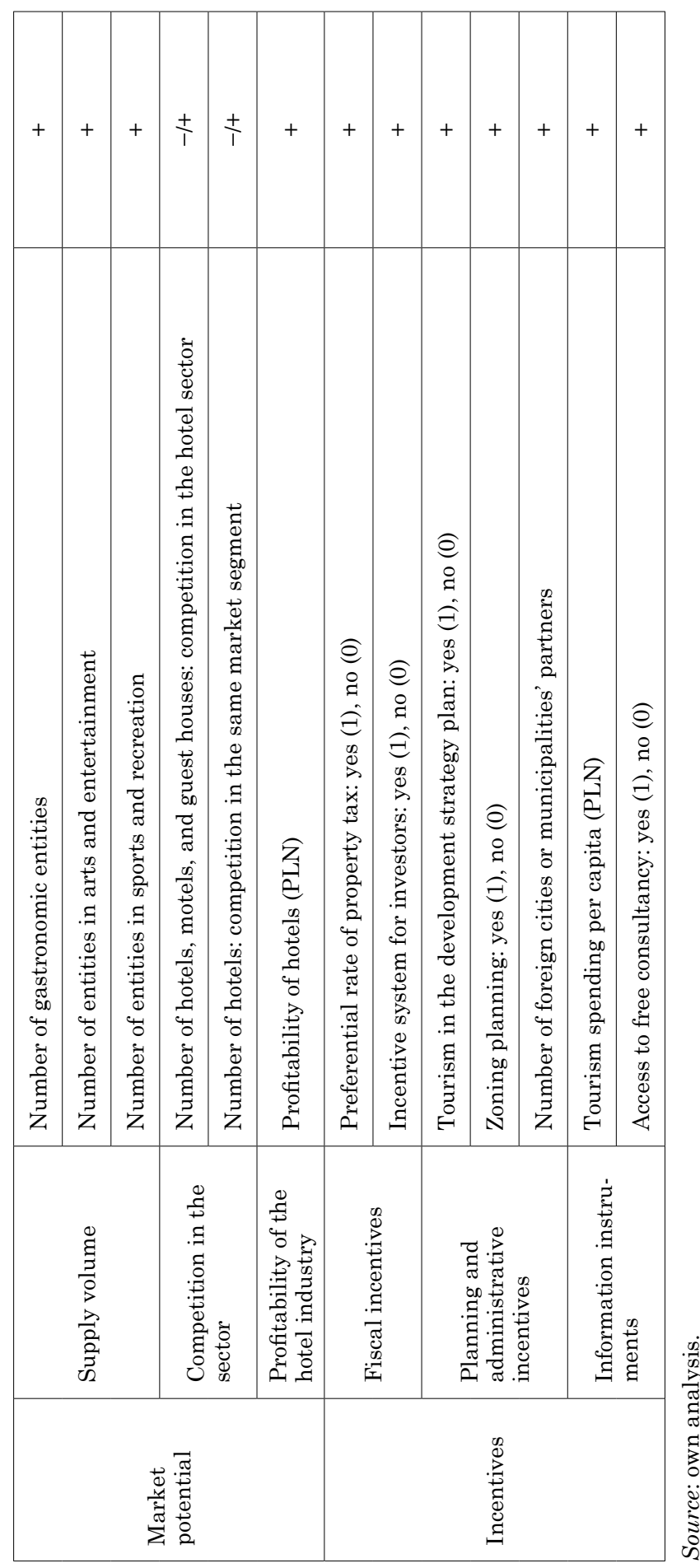


In the third stage of the research, we carried out empirical verification of location factors listed in Table 1 . The verification was objective and was based on an observation of the actual location of newly built hotels in three Polish provinces, in the years 2000-2009. To determine the most important hotel location factors we used: the documentary and statistical method. In the documentary method we obtained statistical data from secondary sources, i.e. from the analysed hotels and municipalities, as well as from the Central Statistical Office in Warsaw. The data collected concerned both hotels, as well as measures that describe the location factors in municipalities. The research was full in character, because it covered all hotels launched in the years 2000-2009 ( $\mathrm{n}=82)$ in all municipalities $(n=408)$ of the analysed provinces.

Within the statistical verification we assessed the informational value of variables, taking into account their abilities and potential discriminatory information (Nermend, 2009).

To assess the ability of the discriminant we used the positional coefficient of variation, and we left those variables, which have a coefficient that satisfies the inequality:

$$
V\left(x_{j}\right) \geq \varepsilon,(j=1,2, \ldots, m)
$$

In accordance with Hellwig (1968), the value of $\varepsilon=10 \%$ was adopted.

The analysis of information capacity of variables was based on the parametric method, proposed by Hellwig (1968). In the set of variables we left these satisfying the condition:

$$
r_{j, j^{\prime}}>r^{*}, \quad\left(j, j^{\prime}=1,2, \ldots, m\right)
$$

In this paper, we adopted the value $\mathrm{r} *=0.5$.

All variables describing the hotel location factors in Table 1 successfully passed the above statistical procedures and have been incorporated into a set of diagnostic variables.

The main statistical method that we used was logistic regression (Hosmer \& Lemeshov, 2000). In this paper two logistic regression models were created (for hotels financed from domestic and foreign capital), where the dependent variable was running $($ yes $=1)$ or not running $($ no $=0)$ a new hotel in the municipal area in a given year. The explanatory 
variables were diagnostic ones (measures describing the location factors) characterising all the municipalities located in the analysed provinces. The study assumed a 2-year delay between the dependent variable and the explanatory variables because, as practice proves, the economic average investment process takes approximately two years.

In the work the stepwise logistic regression with backward elimination of regressors was applied. Therefore, the iterative elimination of subsequent variables with the highest level of ex post significance for the Wald Chi-Square test in the logistic regression model was implemented. This means that at the beginning, the method considered all diagnostic variables and then the variables, which did not have significant impact on improvement of the model accuracy were gradually eliminated. The logistic regression model was based on the algorithm indicated in Table 2.

All calculations were carried out using the SPSS 20 program and statistical conclusions were carried out at the assumed ex ante significance level $\alpha=0.05$.

\section{RESULTS}

Table 2 shows the models for hotels, depending on the origin of capital (the hotels were divided in two groups: domestic capital hotels and foreign \& mixed capital hotels). Both the statistical verification of variables, realised on the basis of an assessment of their informational value, and the use of the algorithm of stepwise logistic regression with backward elimination of regressors allowed for choosing a set of such independent variables that both are statistically significant and give the best fit. By using these statistical procedures we also managed to prevent the problem of too strong correlation of explanatory variables, which could seriously disrupt the reliability of estimates of model parameters. It is evidenced by the models' value of statistic goodness $\left(\chi^{2}=73.27 \mathrm{i}\left(\chi^{2}=122.02\right)\right.$ and the level of probability $(\mathrm{p}=0.00)$. This means that the presented models differ significantly from the one that contains only the intercept, and the location factors considered significantly affect the decisions to run new hotels in the analysed municipalities in 2000-2009. The models also predict well the dependent variables, as evidenced by the values of the Nagelkerke R2 coefficient of determination, which are -0.81 and 0.32 (Table 2). 


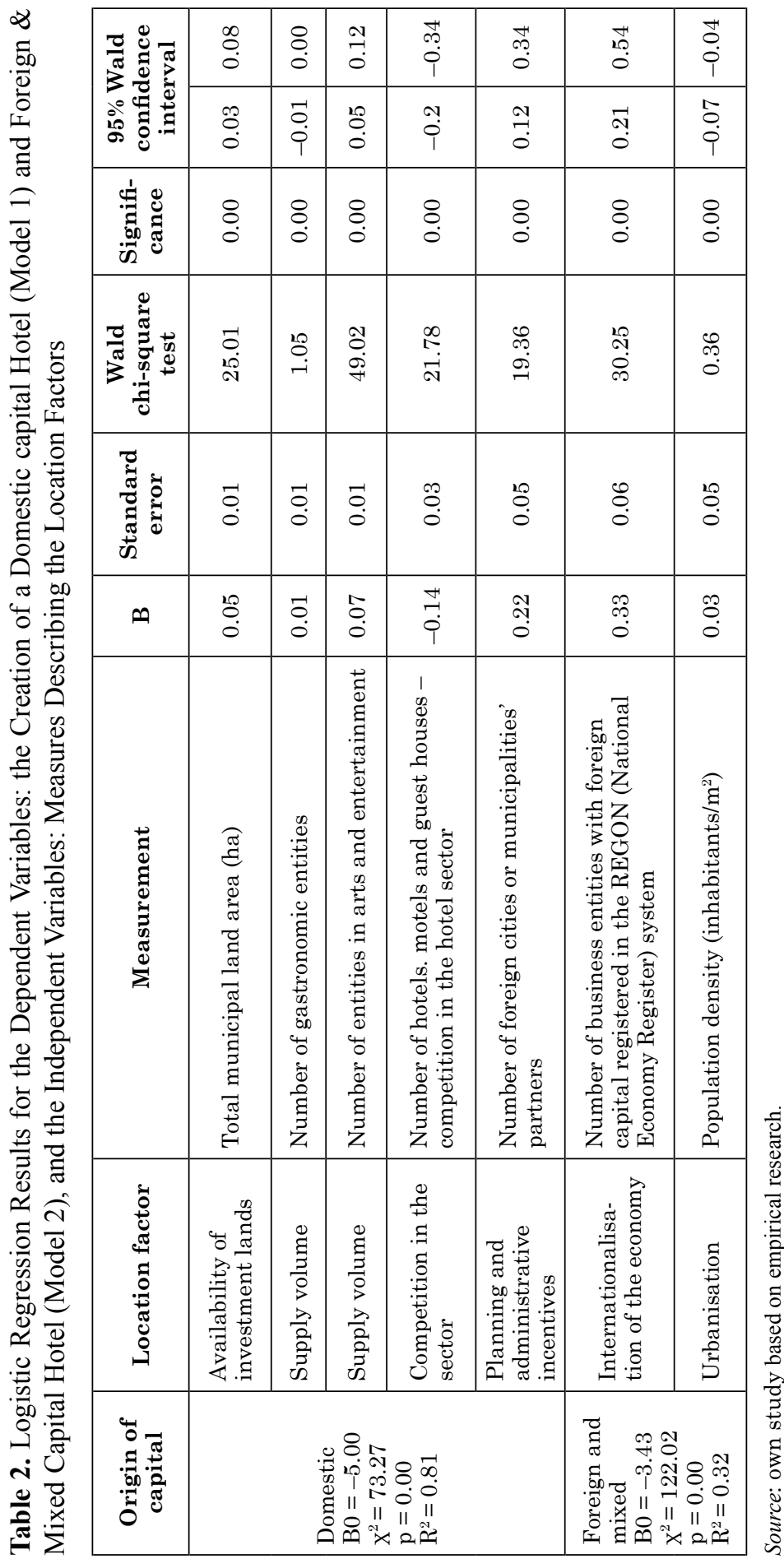


Explanation of terms: B - the model parameter estimates, standard error - asymptotic standard errors of the parameter estimates, Wald chi-square test - the value of the Wald chi-square statistics which examines the significance of the parameters, significance - probability levels for the Wald test, 95\% confidence interval - the lower and upper limit of the $95 \%$ confidence interval of parameters, B0 - the value of the constant (intercept), $\chi^{2}$ - the value of the statistic goodness of the model, $\mathrm{p}$ - the level of probability of the statistic goodness of the model, R2 - the Nagelkerke coefficient of determination.

In the case of domestically financed hotels the following should be considered the most important location conditions: investment incentives (planning and administrative instruments), intensification of competition (the higher the competition, the less likely a new hotel is to rise), the supply of tourist services in gastronomy, arts and entertainment, as well as the availability of investment land (the larger the supply of services, the availability of investment lands the greater the chances for the emergence of a new hotel).

In the case of hotels with foreign and mixed capital the greatest impact on the emergence of a new hotel had: the degree of the economy internationalisation and the urbanisation (the larger the internalisation and urbanisation, the greater the chances for running of a new hotel) (Table 2).

\section{DISCUSSION}

The research reveals the degree of the economy internationalisation as the most important hotel location condition in case of foreign investors. The results of the research by authors such as Barkema, Bell \& Pennings (1996), Johanson \& Vahlne (1990), as well as Ramon Rodriguez (2002), also indicate the importance of this location factor for decisions of foreign investors. In addition, it has been shown that urbanisation is the second most important location factor for foreign hotels. This is partly confirmed by the research by Yang, Wong \& Wang (2012), Zhang, Guillet \& Gao (2012), Obregón-Biosca, Chávez-Usla \& Betanzo-Quezada (2014), Jofre-Monseny, Marin-Lopez \& Viladecans-Marsal (2014), Egan, Chen \& Zhang (2006), Johnson \& Vanetti (2005), Kundu \& Contractor (1999), Martorell, Mulet \& Otero (2012), Chen (2009). It should be noted, however, that they show 
a much greater impact of this factor on the location than it appears from our test results.

In the case of hotels financed from domestic capital the most important location factor selection, according to our research are planning and administrative incentives implemented by local authorities. Findings by Bernini \& Guizzardi (2010), Issahaku \& Francis (2014), and Pin-Ju \& Shin-Yi (2011) confirm this result. According to these studies, incentives affect the attractiveness of the area from the view of potential investors. However, these studies particularly emphasise the importance of fiscal instruments, such as taxes and local fees. This remains in contrast with our results, showing that the most important is the number of foreign cities or municipalities' partners. Possibly the results are related to the border location of the analysed regions, where the intensive cooperation between foreign partner cities and municipalities may contribute to the increased number of foreign tourists.

Surprisingly, the stimulating instruments adopted by local authorities to attract potential investors are not an important factor for hotels financed from foreign capital. This is probably related to the fact that the limited domestic capital funds usually small, independent hotels, for which incentives used by local and regional authorities can have a significant impact (Bernini \& Guizzardi, 2010; Issahaku \& Francis, 2014; Pin-Ju \& Shin-Yi, 2011). Capital constraints of domestic investors make limited possibilities of generating revenue. Domestic investors in competition with foreign capital must look for location benefits (Sala, 2006). However, it is the signal for the national, regional, and local authorities that domestic investors look for a location in which active policy is carried on with incentives aimed at improving the investment attractiveness of spatial units. On the other hand, these factors should be seen as an instrument for creating a tourism policy at the national level for the sustainable development of the hotel market in Poland.

Also the availability of investment areas has turned out an important location factor for the hotels created by domestic capital. The number of investment processes implemented in Poland and capital constraints mentioned above cause a limited access for domestic investors to real estates in attractive tourist areas. During the researched period, the politics for land use planning were not very investor friendly. Many municipalities did not have regional planning programs. 
An intensified competition in the group of domestically financed hotels turned out to be a statistically significant and negative location factor. The increasing competition in the hotel sector means the declining chance to start up a hotel financed by domestic capital in the municipality area. According to the study by Chen \& Dimon (2005) for financially strong foreign investors, this factor can be positive. However, in the case of the national capital a large number of competitors in the sector can be a significant location barrier.

On the other hand, the increasing supply of tourist services in gastronomy, arts, and entertainment increase the attractiveness of investment for domestic capital. This probably results from the fact that tourists, and hence potential hotel investors, look for places, in which a full tourist product exists. A great diversity of tourist services and the organisation of art or entertainment events, improve prospects related to the tourist demand. Similar findings were reported by Dziedzic (1998) in her studies. This is connected with the so-called coordination defect (Garbicz, 2005). It consists in the fact that the new tourist supply has a chance to originate only, if new tourists turn up in a given location (tourist demand). However, new tourists will be interested in visiting the given place only if new tourist suppliers originate there. So the tourist demand depends on the size of provided supply, while an appropriately high supply is not possible without an appropriately high demand. This phenomenon may be observed especially in countries with a medium level of economic development and Poland may be included in this group.

\section{CONCLUSIONS}

The results of the study indicate clearly that there are differences in the location factors for hotels, depending on the origin of investment capital. Factors determining the location of domestically financed hotels differ from those influencing the location of a group of hotel enterprises with mixed or foreign capital.

In contrast, in case of hotels with foreign and mixed capital the degree of the economy internationalisation and urbanisation turned out to be statistically significant location factors

According to our research, the most important factors influencing location of hotels financed by national capital are: investment incentives 
planning and administrative investment incentives, intensification of competition, supply of tourist services in gastronomy, arts, and entertainment, as well as the availability of investment land. In case of hotels with foreign and mixed capital the degree of the economy internationalisation and the urbanisation turned out to be statistically significant location factors. In addition, it should be noted that the list of factors affecting the location of national hotels is much more extensive.

As indicated, an important element in determining the location of the investment is the attractiveness of the region and created investment climate. The results can contribute to a better understanding of the motives of domestic and foreign investors selecting a location and may have implications for economic policies, since they can focus local and regional authorities' attention on important determinants of creating sustainable hotel tourism in Poland. In the authors' opinion, the recommendations to national and local authorities, which are willing to increase the attractiveness of managed municipalities for potential hotel investors may include the following actions:

1. Stimulating actions carried out by local and regional governments, directed towards creating full local and regional tourist products. These actions should be directed to potential hotel investors, and other entities generating the supply in tourist services such as: restaurants, cultural-entertainment, and sports-recreation services.

2. Attracting domestic and foreign investments in the hotel industry as a result of increase in local economies' internationalisation. This should also be related to the intensification of contacts with foreign partner municipalities and to establishing other forms of international cooperation on local, regional, and national level.

3. Attracting foreign direct investments in the hotel industry by stimulating intensification of urbanisation processes.

The analysis of the research results provides an indication of both strengths and weaknesses of the paper. The strengths of the article may include a three-stage examination procedure, including both a specification of location factors of newly built hotels and their exploration and verification. This methodological approach is not used too often. The models presented in the article may be useful for representatives of business practice, e.g. potential investors or authorities in reception areas. Currently, a growing interest in location analyses may be observed, which may assist investors in understanding the market, and 
consequently help them make the right location decision. Authorities in reception areas may in turn be interested in potential directions of improvement of investment attractiveness of municipalities for hospitality, which can contribute to improving the competitiveness of their spatial units. The strength of the paper is also its spatial extent, as the hotel markets in Central and Eastern Europe were not too often taken into account in previous studies.

On the other hand, the potential weakness of the article may include limiting the scope of research to three Polish provinces. Future research should also include other Polish provinces, as well as other countries with a level of economic development similar to Poland, with a particular focus on Central and Eastern Europe. This is particularly justified in the context of the dynamic penetration of these markets by foreign hotel chains. The extension of the spatial range would verify whether the presented models are appropriate in relation to other countries with a similar level of economic development or may depend on characteristics such as market size, cultural aspects, tourism attractiveness, etc. As the constraints of this paper one should consider the relatively short time range, that in future research should be extended. With regard to Poland and other countries of Central and Eastern Europe examining the period before 1990, is however, impossible. This is mainly due to the different economic system, which then prevailed in these countries (centrally planned economy), the consequence of which were: different management conditions, limited development of entrepreneurship, minuscule presence of international investors in hospitality as well as the lack of statistical information from that period. The fact that most of the hotels examined in the study are objects designed primarily for business guests can be considered as another shortcoming of the article. In future research the location factors should therefore consider holiday, transit, or spa hotels.

\section{REFERENCES}

Abrate, G., Capriello, A. \& Fraquelli, G. (2011). When quality signals talk: Evidence from the Turin hotel industry, Tourism Management, 32, 912-921.

Adam, I. \& Amuquandoh, F.E. (2013). Dimensions of hotel location in the Kumasi Metropolis, Ghana, Tourism Management Perspectives, 8(1), 1-8. 
Aissa, S. \& Goaied, M. (2016). Determinants of Tunisian hotel profitability: The role of managerial efficiency, Tourism Management, 52, 478-487.

Alegre, J. \& Cladera, M. (2006). Repeat visitation in mature sun and sand holiday destinations, Journal of Travel Research, 44(3), 288-297.

Assaf, A., Josiassen, A. \& Agbola, F. (2015). Attracting international hotels: Locational factors that matter most, Tourism Management, 47, 329-340.

Barkema, H., Bell, J. \& Pennings, J. (1996). Foreign entry, cultural barriers and learning, Strategic Management Journal, 17, 151-166.

Baum, J. \& Haveman, H. (1997). Love thy neighbour? Differentiation and agglomeration in the Manhattan hotel industry, 1898-1990, Administrative Science Quarterly, 42(2), 304-338.

Bernini, C. \& Guizzardi, A. (2010). Internal and locational factors affecting hotel industry efficiency: Evidence from Italian business corporations, Tourism Economics, 16(4), 883-913.

Broadway, M. (1993). Montreal's changing tourist landscape. Canadian Journal of Urban Research, 2(1), 30-48.

Brouthers, L., Brouthers, K. \& Werner, S. (2000). Perceived environmental uncertainty, entry mode choice and satisfaction with EC-MNC performance, British Journal of Management, 11(3), 183-195.

Buckley, P., Clegg, J., Cross, A., Liu, X., Voss, H. \& Zheng, P. (2007). The determinants of Chinese outward foreign direct investment, Journal of International Business Studies, 38, 499-518.

Canina, L., Enz, C. \& Harrison, J. (2005). Agglomeration effects and strategic orientations: Evidence from the U.S. lodging industry, Academy of Management Journal, 48(4), 565-581.

Carlback, M. (2012). Strategic entrepreneurship in the hotel industry: The role of chain affiliation, Scandinavian Journal of Hospitality and Tourism, 4, 349-372.

Crecente, J., Santé, I., Díaz, C. \& Crecente, R. (2012). A multicriteria approach to support the location of thalassotherapy (seawater therapy) resorts: Application to Galicia region, NW Spain, Landscape and Urban Planning, 104(1), 135-147.

Chen, L. (2013). Research note: A sustainable hypothesis for tourist hotels: Evidence from international hotel chains, Tourism Economics, 6, 1449-1460.

Chen, M. (2010). The economy, tourism growth and corporate performance in the Taiwanese hotel industry, Tourism Management, 31(5), 665-675.

Chen, Y. (2009). Agglomeration and location of foreign direct investment: The case of China, China Economic Review, 20(3), 549-557.

Chen, J. \& Dimou, I. (2005). Expansion strategy international hotel firms, Journal of Business Research, 58(12), 1730-1740. 
Chung, W. \& Kalnins, A. (2001). Agglomeration effects and performance: A test of the Texas lodging industry, Strategic Management Journal, 22(10), 969-988.

Demirbag, M., Tatoglu, E. \& Glaister, K. (2007). Factors influencing perceptions of performance: the case of western FDI in an emerging market, International Business Review, 16(3), 310-336.

Dębski, M. \& Niemczak, K. (2015). The importance of the region's tourism attractiveness in the management of a hotel's promotional activities. International Journal of Contemporary Management, 14(4), 111-129.

Dziedzic, E. (1998). Obszar recepcji turystycznej jako przedmiot zarzqdzania strategicznego. Szkoła Główna Handlowa, Warszawa.

Egan, D., Chen, W. \& Zhang, Y. (2006). The intra-urban location of hotels in the Chinese cities of Beijing, Shanghai \& Shenzhen, China Tourism Research, 2(4), 516-530.

Enz, C., Canina, L. \& Liu, Z. (2008). Competitive dynamics and pricing behavior in US hotels: The role of co-location, Scandinavian Journal of Hospitality and Tourism, 8(3), 230-250.

Ferri, J. (2004). Evaluating the regional impact of a new road on tourism, Regional Studies, 38(4), 409-418.

Garbicz, M. (2005). Niedorozwój a korzyści skali. In: W. Pacho (ed.), Szkice ze współczesnej teorii ekonomii (pp. 11-31). Szkoła Główna Handlowa, Warszawa.

Gawlik, A. \& Parvi, R. (2015). Incentive instruments and appraisal systems in hotel enterprises on the example of the opolskie province, Journal of Economy, Business and Financing, 3(2), 52-57.

Gawlik, A. \& Puciato, D. (2015) Zakres wykorzystania koncepcji zarządzania wiedzą w wybranych biurach podróży zlokalizowanych na obszarze województwa opolskiego, e-mentor, 1(58), 49-54.

Godlewska-Majkowska, H. (2013). Atrakcyjność inwestycyjna regionów Polski na tle Unii Europejskiej. Studia i Analizy Instytutu Przedsiębiorstwa SGH, Warszawa.

Graf, N. (2011). Market structure and demand-side substitutability of chained urban hotel segments, International Journal of Hospitality Management, $1,82-90$.

Grobelna, A. (2015). Role ambiguity: a problem or a challenge facing contemporary hospitality industry. The critical role of employees' creativity, International Journal of Contemporary Management, 14(3), 77-98.

Guizzardi, A. \& Bernini, C. (2010). Internal and locational factors affecting hotel industry efficiency: evidence from Italian business corporations, Tourism Economics, 16(4), 883-913. 
Hadzik, A. \& Grabara, M. (2009). Turystyka a inwestycje i imprezy sportowe, Turystyka i Rekreacja, 5, 119-126.

Hellwig, Z. (1968). Zastosowanie metody taksonomicznej do typologicznego podziału krajów ze względu na poziom ich rozwoju oraz zasoby i strukturę wykwalifikowanych kadr, Przeglad Statystyczny, 4, 307-327.

Hobson, J. (1994). Fengshui: Its impacts on the Asian hospitality industry, International Journal of Contemporary Hospitality Management, 6(6), 21-26.

Hosmer, D. \& Lemeshow, S. (2000). Applied Logistic Regression. Hoboken, John Wiley \& Sons, Inc., New York.

Issahaku, A. \& Francis, E. (2014). Hotel characteristics and location decisions in Kumasi Metropolis, Ghana, Tourism Geographies: An International Journal of Tourism Space, Place and Environment, 16(4), 653-668.

Jofre-Monseny, J., Marin-Lopez, R. \& Viladecans-Marsal, E. (2014). The determinants of localization and urbanization economies: evidence from the location of new firms in Spain, Journal of Regional Science, 54(2), 313-337.

Johnson, C. \& Vanetti, M. (2005). Locational strategies of international hotel chains, Annals of Tourism Research, 32(4), 1077-1099.

Knapová, B. (2010). Theory of decision making in managerial practice, Prace Naukowe Uniwersytetu Ekonomicznego we Wrocławiu, 99, 164-171.

Kojima, K. (1973). A macro-economic approach to foreign direct investment Hitotsubashi, Journal of Economics, 14(1), 1-21.

Kundu, S. \& Contractor, F. (1999). Country location choices of service multinationals: An empirical study of the international hotel sector, Journal of International Management, 5(4), 299-317.

Luo, H. \& Yang, Y. (2012). Spatial Pattern of Hotel Distribution in China. Sun Yatsen University, Guangzhou.

Lado-Sestayo, R., Otero-González, L. \& Vivel-Búa, M. (2014). Impact of the location and market structure in the performance of hotel establishments, Tourism \& Management Studies, 10(2), 41-49.

Lockyer, T. (2005). Understanding the dynamics of the hotel accommodation purchase decision, International Journal of Contemporary Hospitality Management, 17(6), 481-492.

Łoś, A. (2012). Wymiary efektywności i jej pomiar we wspótczesnej turystyce. In: M. Morawski (ed.), Zarzqdzanie wiedza w turystyce a efektywność gospodarki turystycznej (pp. 79-88). Akademia Wychowania Fizycznego, Wrocław.

Martorell, O., Mulet, C. \& Otero, L. (2012). Choice of market entry mode by Balearic hotel chains in the Caribbean and Gulf of Mexico, International Journal of Hospitality Management, 32(6), 217-227. 
Nermend, K. (2009). Vector Calculus in Regional Development Analysis. Physica Verlag. A Springer Company, Berlin-Heidelberg.

Obregón-Biosca, S., Chávez-Usla, J. \& Betanzo-Quezada, E. (2014). Road transport infrastructure and manufacturing location: An empirical evidence and comparative study between Tijuana and Nuevo Laredo, Mexico, Frontera Norte, 26(52), 109-133.

Panek, T. (2009). Statystyczne metody wielowymiarowej analizy porównawczej. Szkoła Główna Handlowa, Warszawa.

Parte-Esteban, L. \& Alberca-Olivera, P. (2015). Determinants of technical efficiency in the Spanish hotel industry: Regional and corporate performance factors, Current Issues in Tourism, 18(4), 391-411.

Pin-Ju, J. \& Shin-Yi, L. (2011). Research note: Resort hotel location, Tourism Economics, 17(4), 925-931.

Polyzos, S. \& Minetos, D. (2011). An ordinal regression analysis of tourism enterprises' location decisions in Greece, Anatolia, 22(1), 102-119.

Przybylska, K. (1999). Korzyści i koszty zwiazane z napływem kapitału zagranicznego do Polski. Akademia Ekonomiczna, Kraków.

Puciato, D. (2012). Reasons for location of selected hotel enterprises in Opole, Infrastructure and Ecology of Rural Areas, 2, 113-120.

Puciato, D. (2013). Wybrane aspekty innowacyjności przedsiębiorstw hotelowych z Beskidu Ślaskiego, International Journal of Contemporary Management, 12(1), 106-114.

Puciato, D. (2016). Attractiveness of municipalities in South-Western Poland as determinants for hotel chain investments, Tourism Management, 57, 245-255.

Puciato, D. \& Dziedzic, E. (2016). The attractiveness of the municipalities of the south-western Polish for hotel investors, Tourism Economics, doi:10.5367/ te. 2016.0539

Puciato, D., Łoś, A. \& Mrozowicz, K. (2013). Franchising as a way of reducing moral hazard in the tourism market, Argumenta Oeconomica, 30(1), 127-147.

Ramon Rodríguez, A. (2002). Determining factors in entry choice for international expansion: The case of the Spanish hotel industry, Tourism Management, 23(6), 597-607.

Romanowska, M. (2008). Podejmowanie decyzji w organizacji. In: M. Strużycki (ed.), Podstawy zarzadzania (pp. 109-135). Szkoła Główna Handlowa, Warszawa.

Roszkowska, E. (2009). Teoria podejmowania decyzji a teorie zarzadzania, Optimum Studia Ekonomiczne, 44(4), 97-118.

Rzepka, A. (2005). Inwestycje zagraniczne a globalizacja gospodarki, Ekonomika i Organizacja Przedsiębiorstwa, 1, 25-33. 
Rynek Hotelarski w Polsce. Raport (2015). Hotelarz, 2, 12-43.

Sainaghi, R. (2011). RevPAR determinants of individual hotels: Evidences from Milan, International Journal of Contemporary Hospitality Management, 23(3), 297-311.

Sala, J. (2006). Internacjonalizacja rynku usług hotelarskich w Polsce, Zeszyty Naukowe Akademii Ekonomicznej w Krakowie, 704, 11.

Shu, J. \& Dai, B. (2002). A comparative study of the spatial distribution of hotels in China, China Tourism Research, 2(1/2), 165-195.

Silva, R. (2015). Multimarket contact, differentiation, and prices of chain hotels, Tourism Management, 48, 305-315.

Sohrabi, B., Vanani, I., Tahmasebipur, K. \& Fazli, S. (2012). An exploratory analysis of hotel selection factors: A comprehensive survey of Tehran hotels, International Journal of Hospitality Management, 31(1), 96-106.

Starzyk, K. (1999). Zagraniczne inwestycje bezpośrednie a transfer technologii do polskiej gospodarki. Akademia Ekonomiczna, Kraków.

Sund, K. (2006). The geographical concentration of hotels in Switzerland and the industry lifecycle, Tourism and Hospitality Planning \& Development, 3(1), $1-18$

Szromek, A., Romaniuk, A. \& Hadzik, A. (2016). The privatization of spa companies in Poland, Health Policy, dx.doi.org/10.1016/j.healthpol.2016.02.011

Ussi, M. \& Wei, J. (2011). The location determinants for hotel foreign direct investment in Zanzibar, Management and Service Science, 8, 105-112.

Wyżnikiewicz, B. (2001). Korzyści z obcego kapitału, Prawo i Gospodarka, 54.

Yang, Y. \& Fik, T. (2011). Agglomeration Effects and Hotel Location: Empirical Analysis from Major China Cities in 2011. AAGAnnual Meeting, Seattle, Washington.

Yang, Y., Hao, L. \& Rob, L. (2014). Theoretical, empirical, and operational models in hotel location research, International Journal of Hospitality Management, $36,209-220$.

Yang, Y., Wong, K. \& Wang, T. (2012). How do hotels choose their location? Evidence from hotels in Beijing, International Journal of Hospitality Management, 31(3), 675-685.

Zhang, H., Guillet, B. \& Gao, W. (2012). What determines multinational hotel groups' locational investment choice in China, Hospitality Management, 31(2), 350-359. 


\section{CZYNNIKI LOKALIZACJI INWESTORÓW KRAJOWYCH I ZAGRANICZNYCH W BRANŻY HOTELARSKIEJ W POLSCE}

\section{Abstrakt}

Tło badań. Wybór lokalizacji hotelu jest jedna z najważniejszych decyzji podejmowanych na etapie przedinwestycyjnym. Lokalizacja, poprzez oddziaływanie na koszty i przychody, wpływa na rentowność i inne wskaźniki efektywności ekonomicznej hotelu.

Cel badań. Celem artykułu jest próba określenia najważniejszych czynników lokalizacji hotelu dla inwestorów krajowych i zagranicznych.

Metodologia. W opracowaniu wykorzystano dedukcję, sondaż diagnostyczny oraz metodę statystyczna. Zakres przestrzenny badań obejmował trzy polskie województwa: dolnoślaskie, opolskie i ślaskie, a zakres czasowy: lata 2000-2009.

Kluczowe wnioski. Analiza wyników badań wykazała, że czynniki lokalizacji hoteli moga być różne dla inwestorów krajowych i zagranicznych. W przypadku hoteli finansowanych z kapitału krajowego, czynniki te obejmowały: dostępność gruntów inwestycyjnych, wielkość podaży turystycznej, nasilenie konkurencji oraz zachęty inwestycyjne ze strony władz publicznych. W odniesieniu do hoteli finansowanych z kapitału zagranicznego głównymi czynnikami lokalizacji okazały się natomiast urbanizacja oraz stopień umiędzynarodowienia gospodarki.

Słowa kluczowe: hotel, lokalizacja, pochodzenie kapitału, bezpośrednie inwestycje zagraniczne, determinanty. 